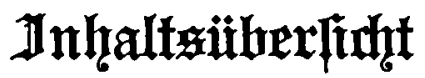

\section{De Tand}

\section{CetI.}

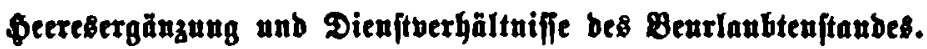

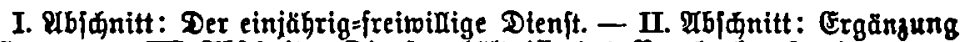

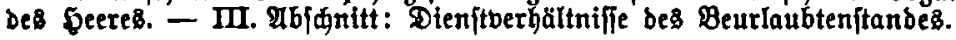

\section{Ceir.}

Đeeresorganijation.

IV. भbfめnitt: OSlieberung unb Uniformierung beş fheeres.

\section{Ceil.}

\section{Snuerer Dienft.}

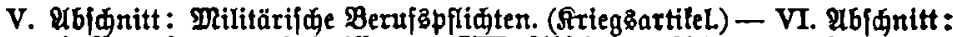

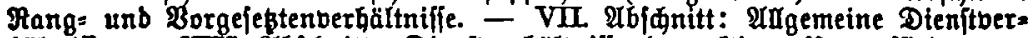
bălniffe. - Vul. Áb/gnitt : Dienfitberbältniffe der altiben unteroffiziere. -

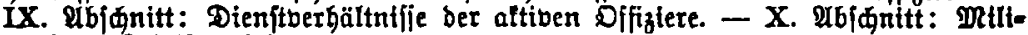

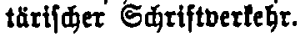

\section{IV. שetr. Berwaltung, Sanitảtzbienft.}

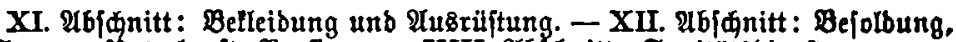

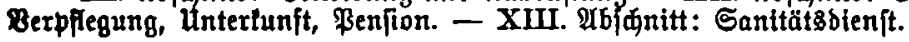

\section{CetI.}

Disziplin, Nedtsiplege, Ghrengeridte, Anzzeidnungen.

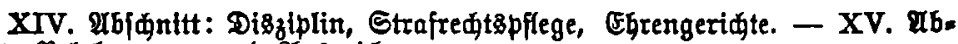



\section{TetI. \\ Oymuaftił, Gyerzieren, Baffen unb Mnnition, Suiefen, Garnijonsbienit.}

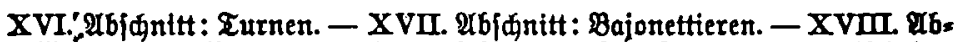

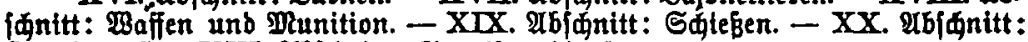
Erergieren. - XXI. भbjđnitt: Barntionsobienjt.

\section{Ceil.}

\section{Dienft in Frelbe (Mianzber).}


Das Selänbe und befjen Darftelung. - XXIV. Ábjđnttt: Zelbbejejtigung. 